\title{
Bermonta karaspēka uzbrukuma pirmās dienas Rīgā 1919. gada 8.-11. oktobrī: Britu misijas redzējums
}

\author{
First Days of Expansion of Bermontd Army towards Riga, October 8-11, 1919: \\ Viewpoint of British Mission
} \author{
Translation and commentaries by \\ Ëriks Jēkabsons, Dr. hist. \\ Latvijas Universitātes Vēstures un filozofijas fakultātes \\ Vēstures un arheoloğijas nodalas profesors \\ Aspazijas bulvāris 5, Rīga, LV-1050 \\ E-pasts:eriks.jekabsons@lu.lv
}

Dokumentus publicēšanai sagatavojis, no ang|u valodas tulkojis un komentējis

1919. gada 8. oktobrī agri no rīta sākās Bermonta komandētās Rietumkrievijas Brīvprātīgo armijas uzbrukums Rīgas virzienā. 9. oktobra vakarā pāri tiltiem uz labo krastu diezgan lielā steigā atkāpās lielākā daḷa Latvijas armijas vienību, mazāku vienību atkāpšanās turpinājās naktī, un, parādoties ienaidnieka avangarda vienībām, pāri tiltiem 10. oktobra rītā pēc ìsas apšaudes uz labo krastu atgāja pēdējās Latvijas armijas vienības, un tilti tika izgriezti vai pacelti. Sekoja mēnesi ilgas cīņas galvaspilsētā, kas noslēdzās tikai 11. novembrī, Latvijas armijai to pilnībā atbrīvojot. Taču 9. oktobrī pilsētā laiku pa laikam sprāga ienaidnieka artilērijas lādiņi un pārlidoja ienaidnieka lidmašīnas, valdības un pašvaldības iestādēs valdīja pilnīgs juceklis un pat panika. Vakarā uz Cēsīm devās valdība un tās iestāžu darbinieki, arī dạ̣a Tautas padomes locekḷu (turpmākajās dienās Ministru prezidents Kārlis Ulmanis un daži citi ministri periodiski ieradās Rīgā, bet pastāvīgi pilsētā atgriezās 12. oktobrī). Sajukums bija arī Apsardzības ministrijā un Armijas virspavēlnieka štābā, karaspēkam tika dota neapdomāta pavēle atkāpties uz Juglas upes pozīcijām aiz pilsētas, un, vienīgi pateicoties dažiem zemākiem komandieriem un armijas virspavēlnieka Dāvida Sīmansona braucienam pār tiltu un apspriedei ar 1. Studentu bataljona komandieri, izdevās izgriezt tiltus un ieņemt aizsardzību gar Daugavu labajā krastā. ${ }^{1}$

Visu šo laiku Rīgā aktīvi darbojās sabiedroto misijas, turklāt vislielākā pārstāvniecība tajās bija Lielbritānijai, kuru pārstāvēja Militārā misija genenēāla Alfrēda Bērta vadībā un Politiskā misija pulkvežleitnanta Stīvena Talentsa vadībā. Pēdējais bija aktīvi iesaistījies politiskajās un militārajās norisēs Latvijā kopš savas darbības 
sākuma, turklāt viens no britu un sabiedroto misiju galvenajiem uzdevumiem kopumā bija atrisināt vācu karaspēka problēmu. Latvijas valdība ar sabiedrotajiem, un īpaši britiem, saistīja cerības par atbalstu jaunajai valstij, tādējādi britu misijas pastāvīgi bija ḷoti labi informētas par situāciju. ${ }^{2}$

8. oktobrī S. Talentss ziṇoja uz Londonu, ka no rīta génerāli A. Bērtu un vinu apmeklējis Ministru prezidents Kārlis Ulmanis un ārlietu ministrs Zigfrīds Anna Meierovics, informējot, ka sācies Bermonta spēku uzbrukums. K. Ulmanis īpaši uzsvēra, ka Latvijas armija cīnās ar "vāciešiem", bet "ne pret krieviem kā tādiem". ${ }^{3}$ Vēlāk rakstītajās atmiṇās S. Talentss atcerējās, ka naktī uz 9. oktobri trijos no rīta viṇu uzmodinājušas jaunformētās latviešu vienības no 1. Studentu bataljona, kuras ar dziesmām soḷoja gar Brunniecības namu. ${ }^{4}$

Turpmāk publicēts Lielbritānijas Politiskās misijas vadītāja S. Talentsa ziṇojums par notiekošo Rīgā Bermonta spēku uzbrukuma pirmajās dienās 9., 10. un 11. oktobrī, ziṇojums atrodas Lielbritānijas Nacionālajā arhīvā Londonā, Ārlietu ministrijas dokumentu kolekcijā. Tajā sniegtā informācija būtiski paplašina Latvijas historiogrāfijā pastāvošo viedokli par norisēm šajā laikā. Būtībā ziņojums atspoguḷo paniku un jucekli, kas valdīja pilsētā un brūkošajā frontē, turklāt parāda, ka Latvijas valdība un armijas virspavēlniecība 9. un 10. oktobrī bija gatavas lūgt Bermontam noslēgt pamieru, lai glābtu škietami bezcerīgo situāciju. Faktiski vienīgi britu nespēja vai nevēlēšanās uzreiz nogādāt līdz radiotelegrāfam virspavēlnieka Dāvida Sīmansona uz karakuǵa sagatavoto lūguma tekstu novērsa tā nosūtīšanu. Minētais spilgti apliecina smago situāciju, ne velti valdība un virspavēlniecība gatavojās spert šādu izmisuma soli. S. Talentss atspoguḷo arī savas misijas darbību un noskaņojumu (briti, līdzīgi Latvijas valdībai, nopietni rēḳinājās ar Bermonta karaspēka drīzu ienākšanu Latvijas galvaspilsētā), tāpat viņa paša un misijas locekḷu redzēto frontē un Rīgā, sarunu gaitu ar Latvijas valdības pārstāvjiem, pilsētā esošo vācu zemessargu vadību, Vācbaltiešu nacionālās komitejas vadību u. c.

Publikācijā sākotnēji sniegts dokumenta originālteksts angḷu valodā, pēc tam - tulkojums latviešu valodā ar komentāriem un skaidrojumiem.

\section{Report [of Steven Tallents] on events in Riga, October $9^{\text {th }}$ to $11^{\text {th }} 1919$. Riga, 9 Oct. 1919}

1. About 3-15 p.m. Capt. Bentley of the Military Mission, who had been employed in the training of the Lettish Army, Mr Copping, the correspondent of the "Daily Chronicle", who had lived with the Mission since his arrival in Riga from Reval on October $8^{\text {th }}$, and a Lettish officer, Captain Crum, went out in motorcar towards the front. They crossed the main town bridge over the Dwina and turned to the north towards the Lettish left flank. On reaching the sandhills, they met a number of Letts in retreat. An officer explained that the two companies had declined to advance because of the heavy machine gun fire opposing them. Capt. Bentley and Mr Copping encouraged these retiring soldiers to hold their ground, promising to go and ask for reinforcements, and the Letts complied. The English party, returning towards the town, found a battalion headquarters and reported what they had seen. Further on they met a detachment of schoolboy recruits, armed for the first time that morning, and were told that these were the only reinforcements available. As they come into the suburbs a few shells were falling among the houses, and 
women and children were crouching under cover of the walls. As they drew near to the bridge, they met a party of more seasoned Latvian soldiers, who, however, explained that they were en route to reinforce the centre. They returned to the British Mission at the Ritterhaus about 5 p.m. Shortly before, an aeroplane had crossed the town several times, and had been met, as had already happened on several occasions, with indiscriminate rifle fire from the streets.

2. About 6-30 p.m. Capt. Dewhurst, Mr Hansen and I went for a walk. The light was then beginning to fail. As we came on the river front, an aeroplane again crossed the town and was again pursued by wild rifle fire. It may here be noted that one of the Riga evening papers published a statement that the Allied ships had that afternoon joined in the firing against an aeroplane. Capt. Curtis of H.M.S. Abdiel and a captain of the French destroyer Aisne both told me personally that this was quite untrue.

3. After calling at the ship we walked along the river side towards the main bridge for about 500 yards. There was apparently an attack proceeding on the Lettish left flank. Occasionally lights were going up in that direction and we could see a fire on the same side. As we turned in from the quay, Mr Ulmanis came by in a car and stopped to speak to us. He was cheerful, and I arranged to send over a case of port for the encouragement of himself and his Cabinet. On returning to dinner, I was handed the following optimistic communique:

"Evening, October $9^{\text {th }}$.

Front hold strong. Certain places changed hands during hot fighting, until they came at last into our possession. Conditions are changing in our favour by every hour.

Spirit of our troops wonderful

(sgd) Chief of the Staff".

4. At 8-30 p.m. Capt. Dewhurst and Mr Student, a Lettish officer attached for liaison and interpreting duties to my Mission, walked down the Jacobstrasse. They first met five transport carts, loaded with men and ammunition, trotting away from the direction of the enemy. They stopped the last cart and were told that the line was "in panic" and that the convoy did not know where they were going. Further on they met small parties of armed men moving in the same direction, and were again told that "the line was broken and in panic". Capt. Dewhurst returned and reported at the Ritterhaus. He then went out again, with Mr Copping and Mr Student, and was told by an officer at the bridge-head that the Lettish left flank had been broken by a strong force of armoured cars, but that some cavalry had gone out to protect the further bridge-head. He was also told that the Lettish right flank was believed to have advanced some eight versts.

5. In the evening I collected all the members of my Mission at the Ritterhaus except Capt. Farrow, whom I judged it best to leave in hospital. Four of the servants went to a neighbouring flat for the night and two of them were left in their flat by the garage. Capt. Dewhurst, who went in the Ford car to fetch Mr Ellis and Mr Collas, reported some twenty carts halted by the roadside in the Alexander Boulevard, knots of men retreating and a complete absence of any guards for the streets.

6. Shortly before deciding to call all members of the Mission to the Ritterhaus, I went up to the quarters of the Military Mission and had some conversation with General Burt and Capt. Kayserling, formerly A.D.C. to Colonel Alexander in his command of the Landeswehr and then in charge of the Landeswehr headquarters in Riga. A proposal had been made that his men, who would not take part in the fighting against the 
German-Russian forces, should relieve the Lettish guard over the Ritterhaus. I thought it well to make it clear to Capt. Kayserling, having regard to the possibly far-reaching effects of the action of the Landeswehr in this crisis, that we could take no responsibility for advising him. Knowing him personally, I expressed the view that the state of affairs created by Bermondt's attack could hardly be allowed to stand in the long run, and that the ultimate relations between Balts and Letts might be permanently affected by the Landeswehr's attitude at this juncture. Capt. Kayserling said that he understood that he had his own orders "from the Landeswehr" to remain quietly in Riga. He also suggested that this step had been tacitly agreed between himself and Colonel Kalnin of the Lettish Staff, in frequent conversations bearing on the point.

7. Another case which had to be settled the same evening was that of our Lettish liaison officer. Mr Student. Upon his raising the point with me I said that, if he proposed to stay with us, we would take him away with us, if we went. But I said we could not be responsible for his future, and I pointed out that his leaving Riga at this point might prevent his ever returning. He elected to take his chance with us, and I asked him to go and put on plain clothes and join us in the Ritterhaus for the night.

October $10^{\text {th }}$

8. About 8 o'clock on October $10^{\text {th }}$, Mr Ulmanis, Mr Meierovics, General Simonsen and Colonel Kalnin drove up to the Ritterhaus. I went down to meet them and brought them in to have some coffee, at which General Burt joined us. They handed us the copy of a wireless message from General Youdenich, of which the following is a translation: ---

"North-Western Front. To the Russian officers who have remained true to their duty. I command volunteers to place themselves immediately under the orders of their senior. The representative of the British Mission will join them. Take all measures for instant departure by sea to unite with the North-Western Army.

Original signed by General of Infantry YOUDENICH.

Major-General VANDALY and KONDOUREV.

By order of the Chief of the North-Western Front I wish to bring to your notice that he has to-day issued the following command to troops under his charge:

Order by Chief in command of All Russian armed forces of North-Western Front.

No. 73, 9/X/19. Narva. As Colonel Belmont has not executed one of my commands to the time stated and has even started hostilities against the Lettish troops, I declare to all that he is a traitor to his country, and exclude him and those under his command from the Roll."

Mr Ulmanis also urged the importance to the Letts of an armistice. General Burt promised that he would give any help he could in getting a message transmitted to the attacking force (e.g. by ship's wireless). But we both held the view that the British representatives could not act officially in the matter, except on pure grounds of humanity. Mr Ulmanis asked if the Entente would help them. General Burt and I said we could not think that they would not take drastic action, but had no information from the west.

9. After Mr Ulmanis had left, I had some conversation with Cap. Orbeson, of the American Relief Administration, who said that he should remain in Riga if the Germans entered it, and engage in his purely humanitarian work. I mentioned to him that I was, among other things, representing the Supreme Economic Council and could, if necessary, leave an officer under that heading to keep him company. He was favourably disposed to this idea, and I said that I would consider it further. 
10. During the morning the question of pourparlers for an armistice was brought up from various quarters. General Burt several times asked my opinion on points which arose in this connection, and I took the line that while firing was a hot and uncontrolled as it then was on the river front, it was little use trying to establish touch with the enemy. I also expressed to him the view that Colonel Bermondt could only agree to an armistice on condition of the town being evacuated by the Letts, and that unless the Lettish Command were prepared to give this order, which they said they were not, it was useless to try and open pourparlers on the front.

11. At one stage the following message from General Simonsen was actually brought to the Mission for transmission:---

"To avoid destroying the town and losses of civil inhabitants, I suggest to stop fighting and begin pourparlers about an armistice and to find out the reasons why the bloodshed has begun and to find the means to stop it/

(sgd) General Simonsen

Commander-in Chief of the Army of Latvia."

During the morning also a messenger going down to the quay found that the two destroyers had left. Later Capt. Burgess came up from H.M.S. Abdiel and reported that she was moored in the stream about half-an-hour's walk from Ritterhaus. On this, I agreed with General Burt that we would send on board all officers not directly required, and I started all officers except Capt. Dewhurst, Sir Victor Warrender and myself. They came back, however, about an hour later with the news that the ships had both disappeared, and brought rumours from Lettish sources as to their having been fired on by the attacking forces.

I discussed at the same time with Capt. Kayserling how to send a message to Colonel Alexander, instructing him to leave the Landeswehr and make for the nearest British Mission. But on attempting to send this message, Capt. Kayserling found he could not secure communication.

12. Directly after lunch Baron Fircks, the President of the Baltic National Committee, came to have a talk with me. He had just seen on the Nicolai strasse the body of a young boy lying with his school books beside him, and was evidently glad to quiet his nerves by talking. He deplored Bermondt's adventure, as he had several times deplored its probability to me before the event. He had personally pleaded at Mitau for the avoidance of a march on Riga, but he thought that Bermondt, believing Dvinsk to have fallen to the Poles, desired to open his escapade by some dramatic capture, for the sake of attracting volunteers from Germany. He saw little hope for the Baltic population in the provinces. If the Letts and Estonians swept back over Riga, they had no hope for the future.

13. At 5-45 p.m. Colonel Luters of the General Staff came and told us what he knew of the position. The Letts were holding the right bank of the Dwina firmly and had orders in no circumstances to withdraw. The Latvian and Estonian Governments were consulting by telephone, and Estonian help was expected. Mr Ulmanis had also stated that help from Poland was likely. They had extricated all their forces from the further side of the Dwina the night before, including guns and cavalry. Shells were coming down to them from Estonia.

Colonel Luters raised a question about the number of the Landeswehr guard in the Ritterhaus, and their presence in their usual headquarters opposite. He said they mistrusted the presence of the Landeswehr so near to the bridge, and wanted to concentrate them 
in the barracks at 37 Alexander Strasse. We left him to discuss the position with Capt. Kayserling, who afterwards expressed to me his uneasiness about the intentions of Colonel Luters, whom he mistrusted.

14. During the whole day rifle fire was continuous on the river front. A considerable number of light shells fell from fifty to a hundred yards from the Mission, one bursting close to Paymaster Lt-Commander Stoddart on his return from search for H.M.S. Abdiel. I went for a walk through the town after dinner and visited some of the places where most shells fell. Outside the War Office, at which several were successfully directed, the body of a young men was still lying on the pavement where a shell had caught him. Further on, the top storey of a building close by the Wireless Station was blazing like an open fire. The Town Fire Brigade, however, arrived while I was watching it. In general, the streets were empty, except for patrols of students and others who were acting as police. The town was quiet and orderly.

15. Finally, about 11 p.m. Major Keenan rung us from Neu Myulgraben, down by the mouth of the river, where he had landed in a motor launch, and Capt. Dewhurst took a car down to bring him in. About 1 a.m. in the morning Major Keenan arrived, and General Burt provisionally arranged with him for all the officers whom we had attempted to evacuate that morning, to go down on foot to the mouth of the river. After hearing, however, from captain Dewhurst an account of the difficulties of the road, I obtained General Burt's agreement to a postponement of the plan for that night.

October $11^{\text {th }}$.

16. About 9 a.m. a copy of a message, of which the following is a translation, was brought in to me with a request that Colonel Kalnins might come and discuss it with General Burt and myself:---

"To the Commander of the Lettish Army. The threat to my flank from the side of the Letts and Estonians has been victoriously resolved by my troops. My base has been completely secured. To avoid further brotherly bloodshed, I offer you an armistice and pourparlers in Mitau, and call you to combined operations against the Bolsheviks. I await your reply by radio.

The Commander of the Western Army

Colonel Avaloff-Bermondt."

General Burt arranged that he and I should go down to the War Office instead of bringing Colonel Kalnin to the Ritterhaus, and we met there General Simonsen, Colonel Kalnin, Colonel Luters, Colonel du Parquet and Capt. Orbeson. General Simonsen said that they thought of answering simply that they would have no dealings with a man who had been declared a traitor by General Youdenich. I suggested to General Burt that the answer, while it should be brief should, for the sake of propaganda among his own troops, dispose of Bermondt's claim to victorious action. I understand, however, that at the time of closing this dispatch (the evening of October $12^{\text {th }}$ ) no answer has been sent to Bermondt's message.

S. G. Tallents 
[Stivena Talentsa ${ }^{5}$ ziṇojums par notikumiem Rīgā 9.-11. oktobrī. Riga, 1919. gada 9. oktobris ${ }^{6}$

1. Apmēram 3.15 pēcpusdienā kapt.[einis] Bentlijs ${ }^{7}$ no Militārās misijas, kurš bija nodarbināts Latvijas armijas apmācī̌anā, [laikraksta] Daily Chronicle korespondents Kopinga $^{8}$ kungs, kurš dzīvoja kopā ar misiju, kopš ieradās Rīgā no Tallinas 8. oktobrī, un latviešu virsnieks kapteinis Krūms ${ }^{9}$ automašīnā devās uz fronti. Viņi šķērsoja galveno pilsētas tiltu pāri Daugavai un pagriezās uz ziemeḷiem latviešu kreisā spārna virzienā. Sasnieguši smilšu kāpas, viņi sastapa grupu latviešu, kuri atkāpās. Virsnieks pastāstīja, ka divas rotas atteikušās doties uz priekšu, jo pret tām vērsta stipra ložmetēju uguns. Kapt. Bentlijs un Kopinga kungs aicināja šos karavīrus turēt savas pozīcijas, solot iet un prasīt, lai tiktu nosūtīti papildspēki, un latvieši paklausīja. Angḷu grupa, atgriežoties pilsētas virzienā, atrada bataljona štābu un pastāstīja, ko bija redzējuši. Pēc tam viṇi sastapa vienību no jauniesauktiem skolniekiem, ${ }^{10}$ kas tikko no rīta pirmo reizi bija sañēmuši šautenes, turklāt angḷiem tika pateikts, ka tie ir vienīgie pieejamie papildspēki. Kad angḷi ienāca priekšpilsētā, starp namiem sprāga vairāki lielgabala lādiņi, un sievietes un bērni sakņupuši slēpās sienu aizsegā. Tuvojoties tiltam, viṇi sastapa pieredzējušāku latviešu karavīru grupu, kuri tomēr skaidroja, ka atrodas ceḷā, lai pastiprinātu centru. Angḷi atgriezās britu misijā Bruṇniecības namā ${ }^{11}$ apmēram 5 pēcpusdienā. İsi pirms tam vairākas reizes pilsētai pāri pārlidoja lidmašīna, kura tika sagaidīta ar juceklīgu šauteņu uguni no ielām, kā jau iepriekš dažos gadijumos bija noticis.

2. Apmēram 6.30 pēcpusdienā kapt. Djūhērsts, ${ }^{12}$ Hansena $^{13}$ kungs un es devāmies pastaigā. Tajā laikā sāka krēslot. Kad mēs pienācām pie upes, pāri pilsētai atkal pārlidoja lidmašīna, un to atkal pavadīja intensīva šauteņu uguns. Šeit jāatzīmē, ka viena no Rīgas vakara avīzēm publicēja ziņojumu: saskaṇā ar to sabiedroto kuği tajā pēcpusdienā pievienojušies šaušanai pa lidmašīnu. V.[iṇa] M.[ajestātes] K. [uğa] Abdiel kapt. Kērtiss ${ }^{14}$ un franču mīnu kuğa Aisne kapteinis abi man personiski teica, ka tā [informācija] ir pilnīgi nepatiesa.

3. Pēc kuğa apmeklējuma mēs apmēram 500 jardus ${ }^{15}$ pagājām pa upes krastu galvenā tilta virzienā. Tur acīmredzami notika uzbrukums latviešu kreisajam spārnam. Laiku pa laikam tajā virzienā bija redzamas augšupejošas gaismas un arī šāvieni tajā pašā pusē. Kad mēs nogriezāmies no piestātnes, parādījās Ulmaņa ${ }^{16}$ kungs automašīnā, viņš apstājās, lai ar mums aprunātos. Viņš bija mundrs, un es nokārtoju portvīna kastes nosūtīšanu, lai iedrošinātu viņu pašu un viņa [Ministru] kabinetu. ${ }^{17}$ Kad es atgriezos uz vakariṇām, man pasniedza šãdu optimistisku paziņojumu:

"9. oktobra vakars.

Frontē stāvoklis stingrs. Daži punkti karstā cīṇā gāja no rokām rokās, bet beigu beigās palika mūsu rokās. Ar katru stundu mūsu stāvoklis uzlabojas.

Armijas garastāvoklis apbrīnojami teicams un sajūsma milzīga.

(paraksts) Štāba priekšnieks."18

4. 8.30 vakarā kapt. Djūhērsts un Studenta ${ }^{19}$ kungs, latviešu virsnieks, kurš bija mums piesaistīts sakariem un tulkošanas pienākumiem manā misijā, nogāja lejup pa Jēkaba ielu. Vispirms vini sastapa piecus kravas vezumus, pilnus ar vīriem un munīciju, kas brauca ienaidniekam pretējā virzienā. Vini apturēja pēdējos ratus, un [tajos sēdošie] pateica, ka frontes līnija "ir panikā" un ka konvojs pats nezināja, uz kurieni dodas. Tālāk viṇi sastapa mazas bruṇotu vīru grupas, kas devās tajā pašā virzienā, un vinniem atkal tika sacīts, ka “frontes līnija ir pārrauta un to pārṇēmusi panika”. Kapt. Djūhērsts atgriezās Bruṇniecības 
namā un pastāstīja par redzēto. Pēc tam viņš atkal devās laukā kopā ar Kopinga kungu un Studenta kungu, turklāt virsnieks pie priekštilta viṇam pastāstīja, ka latviešu kreiso spārnu satriekuši lieli spēki ar bruņotajiem automobililiem, taču kāda kavalērija devusies uz priekšu, lai aizsargātu priekštiltu. Tāpat viņam pateica, ka latviešu labais spārns it kā pavirzỉjies uz priekšu astoṇas verstis. ${ }^{20}$

5. Vakarā es sapulcināju Bruṇniecības namā visus savas misijas locekḷus, izṇemot kapt. Ferovu, ${ }^{21}$ kuram, es domāju, labāk bija palikt slimnīcā. Četri kalpotāji vakarā devās uz kaimin,os esošo dzīvokli, un divi no viṇiem palika savā dzīvoklī pie garāžas. Kapt. Djūhērsts, kurš automašīnā Ford devās pakal Elisa ${ }^{22}$ kungam un Kolasa ${ }^{23}$ kungam, ziṇoja, ka Aleksandra bulvārī aptuveni divdesmit pajūgi bija apstādināti gar ceḷa malu, ${ }^{24}$ karavīru grupas atkāpās un trūka jebkādu sargu kārtības uzturēšanai ielās.

6. İsi pirms izlemšanas visus misijas locekḷus sapulcināt Bruṇniecības namā es uzgāju augšā uz Militārās misijas telpām, un man bija saruna ar generāli Bērtu ${ }^{25}$ un kapt. Keizerlingu ${ }^{26}$ - bijušo pulkveža Aleksandera ${ }^{27}$ A.D.C. ${ }^{28}$ landesvēra pavēlniecībā, tagadējo landesvēra mītnes priekšnieku Rīgā. Tika izteikts priekšlikums, lai viņa vīri, kuri nepiedalās cīṇā ar vācu-krievu spēkiem, nomaina latviešu sargus Bruṇniecības nama apsardzē. Es domāju, bija pareizi atklāti pateikt kapt. Keizerlingam, ka, ņemot vērā iespējamās tālejošās sekas, kādas varētu būt landesvēra rīcībai šajā krīzē, mēs nevaram uzṇemties atbildību un ieteikt viņam kaut ko darīt. Pazīdams viṇu personiski, es paudu viedokli, ka Bermonta ${ }^{29}$ uzbrukuma radītais lietu stāvoklis nevar tikt pieḷauts ilglaicīgi un ka landesvēra attieksme šajā konfliktā var pastāvīgi ietekmēt vācbaltiešu un latviešu galīgās attiecības. Kapt. Keizerlings sacỉja, ka viņš saprot un viṇam ir pašam savas pavēles "no landesvēra" klusu palikt Rīgā. Viṇš arī sacīja, ka biežajās sarunās par šo tēmu starp viṇu un latviešu štāba pulkvedi Kalninuu ir panākta klusa vienošanās spert šādu soli. ${ }^{30}$

7. Otrs jautājums, kas bija jāatrisina tajā pašā vakarā, bija par mūsu latviešu sakaru virsnieku Studenta kungu. Kad viņš man ieminējās par šo, es sacīju, ka gadījumā, ja viņš izlems palikt ar mums, mēs paņemsim vinu sev līdzi, ja aiziesim no šejienes. Tomēr es uzsvēru, ka mēs nevaram uzn,emties atbildību par viṇa nākotni, un norādīju, ka gadījumā, ja viņš šajā brīdī aizbrauks no Rīgas, tāds solis vēlāk padarīs neiespējamu viņa atgriešanos. Viṇš izvēèejās izmantot iespēju [palikt] kopā ar mums, un es lūdzu viṇu iet un pārộērbties civilajās drēbēs un vakarā pievienoties mums Bruṇniecības namā. ${ }^{31}$

10. oktobris.

8. 10. oktobrī apmēram plkst. 8 no rīta Ulmaņa kungs, Meierovica ${ }^{32}$ kungs, ǵenerālis Sīmansons ${ }^{33}$ un pulkvedis Kalniņš piebrauca pie Bruņniecības nama. Es nogāju lejā vinusus sagaidīt un ieaicināju iekšā uz kafiju, ${ }^{34}$ kur mums pievienojās generālis Bērts. Viṇi nodeva mums bezdrāts telegrammu no generāḷa Judeņiča, ${ }^{35}$ kuras tulkojums ir šāds:

"Ziemeḷrietumu fronte. Krievu virsniekiem, kuri palikuši uzticīgi savam pienākumam. Es pavēlu brīvprātīgajiem nekavējoties stāties sava vecākā komandiera rīcībā. Britu misijas pārstāvis viniiem pievienosies. Spert visus soḷus, lai nekavējoties izbrauktu jūrā un pievienotos Ziemeḷrietumu armijai.

Oriǵinālu parakstījis infantērijas génerālis JUDEN̦IČS.

G̦enerālmajors VANDAMS ${ }^{36}$ un KONDIREVS. ${ }^{37}$

Pēc Ziemel̦rietumu frontes virspavēlnieka pavēles es vēlos vērst jūsu uzmanību, ka viņš šodien izdeva šādu pavēli sev pakḷautajam karaspēkam:

Visu Krievijas Ziemeḷrietumu frontes brun,oto spēku virspavēlnieka pavēle. Nr. 73, 9/X/19. Narva. Sakarā ar to, ka pulkvedis Bermonts ${ }^{38}$ lìdz šim nav izpildijis nevienu 
no manām pavēlēm un ir pat uzsācis karadarbību pret Latvijas karaspēku, es pasludinu visiem, ka viņš ir savas valsts nodevējs, un izslēdzu viṇu un zem viṇa pavēlēm esošos no armijas sarakstiem."

Ulmaņa kungs tāpat uzsvēra, cik svarīgs latviešiem ir pamiers. G̦enerālis Bērts apsolīja sniegt visu iespējamo palīdzību, lai organizētu ziṇas nosūtīšanu uzbrūkošajiem spēkiem (t. i., ar kuǵa bezdrāts telegrāfu). Taču mēs abi uzskatījām, ka britu pārstāvji šajā lietā nevar darboties oficiāli, izṇemot situāciju, kad runa ir par tīri humanitāriem jautājumiem. Ulmaṇa kungs jautāja, vai Anatnte varētu sniegt viniem palīdzību. G̦enerālis Bērts un es sacījām - mēs nedomājam, ka Antante varētu nespert enerğiskus soḷus, taču mums nav informācijas no Rietumiem. ${ }^{39}$

9. Pēc tam, kad Ulmana kungs bija aizgājis, man bija saruna ar kapt. Orbisonu ${ }^{40}$ no Amerikas Palīdzības administrācijas, ${ }^{41}$ viņš teica, ka viṇam jāpaliek Rīgā, ja tajā ienāks vācieši, un jāturpina humanitārais darbs. Es pieminēju viņam, ka, cita starpā, pārstāvu Augstāko saimniecisko padomi un varu, ja nepieciešams, atstāt virsnieku ar attiecīgu uzdevumu, kas sastādītu viṇam kompāniju. Viṇš pret šo ideju izturējās atsaucīgi, un es apsolīju tālāk to apsvērt.

10. [Šajā] rītā jautājums par pamiera sarunām tika izvirzīts no dažādām pusēm. G̦enerālis Bērts vairākas reizes prasīja manu viedokli jautājumos, kuri radās šajā saistībā, un es paudu pārliecību, ka tikmēr, kamēr notiek tik intensīva un nekontrolēta apšaudīšanās, kāda tajā brīdī bija vērojama uz upes līnijas, nav lielas jēgas mēǵināt stāties sakaros ar ienaidnieku. Es arī viņam paudu uzskatu, ka pulkvedis Bermonts varētu piekrist pamieram vienīgi ar nosacìjumu, ka latvieši atstāj pilsētu, un [teicu], ka latviešu pavēlniecība nav gatava dot tādu pavēli, turklāt viṇi apgalvoja, ka nav tam gatavi, līdz ar to nav jēgas mēgeināt uzsākt sarunas frontes līnijā.

11. Kādā brīdī uz misiju tālāknosūtīšanai tika atnests ziņojums no generāḷa Sīmansona:

"Lai izvairītos no pilsētas izpostīšanas un civiliedzīvotāju zaudējumiem, es piedāvāju pārtraukt karadarbību un uzsākt sarunas par pamieru, kā arī noskaidrot iemeslus, kāpēc slaktinš̌ ir sācies, un atrast līdzekḷus, kā to apturēt.

(paraksts) Ģenerālis Sīmansons

Latvijas armijas virspavēlnieks."

Tāpat šajā rītā ziņnesis, kas devās lejup uz piestātni, konstatēja, ka divi mīnukugíi ir aizbraukuši. Vēlāk ieradās kapt. Bēržess ${ }^{42}$ no V.[iṇa] M.[ajestātes] K. [uǵa] Abdiel un informēja, ka kug̣is ir pietauvots upē apmēram pusstundas gājiena attālumā no Bruṇniecības nama. Pamatojoties uz šo, mēs ar generāli Bērtu vienojāmies, ka nosūtīsim uz klāja visus virsniekus, kuri nav tieši vajadzīgi, un es nosūtīju visus virsniekus, izṇemot kapt. Djūhērstu, seru Viktoru Varenderu ${ }^{43}$ un sevi pašu. Tomēr apmēram pēc stundas viṇi atgriezās ar ziṇu, ka abi kug̣i ir pazuduši, kā arī atstāstỉja baumas no latviešu avotiem, ka uzbrūkošais karaspēks kuǵus apšaudījis.

Tajā pašā laikā es ar kapt. Keizerlingu apspriedu, kā nosūtìt ziṇu pulkvedim Aleksanderam ar instrukciju viņam pamest landesvēru un doties uz tuvāko britu misiju. Taču, mēgeinot nosūtìt šo ziņu, kapt. Keizerlings konstatēja, ka viņš nevar nodrošināt sakarus.

12. Uzreiz pēc pusdienām uz sarunu ar mani ieradās barons Firksss ${ }^{44}$ - Vācbaltiešu nacionālās komitejas prezidents. Vinš̌ tikko Nikolaja ielā bija redzējis jauna zēna līḳi ar apkārt izmētātām skolas grāmatām un bija acīmredzami priecīgs, ka varēja nomierināt nervus sarunā. Viņš pauda nožēlu par Bermonta dēku, kā jau vairākas reizes bija paudis man nožēlu par tās iespējamību pirms šì notikuma. Viņš personiski Jelgavā bija aicinājis 
izvairīties no uzbrukuma Rīgai, taču domāja, ka Bermonts, būdams pārliecināts par Daugavpils krišanu poḷu rokās, vēlas atklāt savu eskapādi ar kādu dramatisku soli, lai piesaistītu brīvprātīgos no Vācijas. Viṇš saskatīja maz izredžu provinču vācbaltiešu iedzīvotājiem. Ja latvieši un igauņi dos atbildes triecienu pāri Rīgai, vācbaltiešiem nav nākotnes izredžu.

13. 5.45 pēcpusdienā ieradās pulkvedis Luters ${ }^{45}$ no G̦enerālštāba ${ }^{46}$ un izstāstīja mums, kas zināms par [pašreizējo] stāvokli. Latvieši stingri turēja Daugavas labo krastu, un viņiem bija dota pavēle neatkāpties nekādos apstākḷıs. Latvijas un Igaunijas valdības apsprieda situāciju pa telefonu, un bija sagaidāma Igaunijas palīdzība. Ulmaņa kungs arī informēja, ka ticama ir palīdzība no Polijas. ${ }^{47}$ Iepriekšèjā naktī latvieši bija izveduši visus savus spēkus no Daugavas otras puses, ieskaitot lielgabalus un kavalēriju. Viniiem sāka pienākt artilērijas lādiņi no Igaunijas.

Pulkvedis Luters izvirzīja jautājumu par landesvēra sargu skaitu Bruṇniecības namā un par viņu atrašanos to parastajā štāba mītnē iepretim. Viņš sacīja, ka latvieši nejūtas droši, ja landesvērs atrodas tik tuvu pie tilta, un vēlas tos koncentrēt kazarmās Aleksandra ielā 37. ${ }^{48}$ Mēs atstājām viṇu apspriest stāvokli ar kapt. Keizerlingu, kurš vēlāk pauda man bažas par pulkveža Lutera nodomiem, kuram tas neuzticējās.

14. Visas dienas garumā turpinājās šauteņu uguns uz upes līnijas. Ievērojams skaits vieglo lādinu nokrita piecdesmit līdz simts jardu attālumā no misijas, viens sprāga netālu no [misijas] kasiera leitnanta-komandiera ${ }^{49}$ Stodarta, $^{50}$ kad viņš atgriezās no V.[iṇa] M.[ajestātes] K. [uğa] Abdiel meklējumiem. Pēc vakariņām es devos pastaigā cauri pilsētai un apmeklēju dažas vietas, kur bija nokritusi lielākā daḷa lādiṇu. Pie Apsardzības ministrijas, uz kuru sekmīgi bija tēmēti daži lādiṇi, jauna vīrieša līḳis joprojām gulēja uz ietves, kur lādiņš bija viņu sasniedzis. Tālāk uz priekšu, netālu no Bezdrāts telegrāfa stacijas, ar atklātu liesmu dega mājas augšējais stāvs. Taču pilsētas ugunsdzēsēju brigāde ieradās, kamēr es vēroju notiekošo. Kopumā ielas bija tukšas, izṇemot studentu un citas patrulas, kuras darbojās kā policisti. Pilsēta bija mierīga un kārtīga. ${ }^{51}$

15. Beidzot ap plkst. 11 vakarā majors Kīnens ${ }^{52}$ piezvanīja mums no Jaunmīlgrāvja, lejup pie upes grīvas, kur viņš bija izkāpis krastā no motorlaivas, un kapt. Djūhērsts ar mašīnu devās vinnam pakal,. Ap 1 naktī majors Kīnens ieradās, un generālis Bērts provizoriski vienojās ar viṇu, ka visi virsnieki, kurus bijām mēginājuši evakuēt no rìta, kājām dosies uz upes grīvu. Tomēr, uzklausījis kapteiņa Djūhērsta stāstījumu par grūtībām ceḷā, es panācu, ka ğenerālis Bērts piekrīt atlikt plāna izpildi šajā naktī.

11. oktobris.

16. Ap 9 no rīta man tika atgādāts paziņojuma noraksts, kura tulkojums ir šeit pievienots, kopā ar lūgumu atḷaut pulkvedim Kalniņam ierasties un ar generāli Bērtu un mani pārrunāt to:

"Latvijas armijas komandierim. Mans karaspēks ir uzvaroši novērsis apdraudējumu manam spārnam no latviešu un igauņu puses. Mana bāze ir tikusi pilnībā nodrošināta. Lai izvairītos no tālāka brāḷu savstarpēja slaktiṇa, es piedāvāju jums pamieru un sarunas par to Jelgavā un aicinu jūs apvienot spēkus pret boḷševikiem. Es gaidu jūsu atbildi pa radio.

Rietumu armijas komandieris

Pulkvedis Avalovs-Bermonts."

G̦enerālis Bērts nokārtoja, ka viņš un es dodamies uz Apsardzības ministriju tā vietā, lai pulkvedis Kalniņš ierastos Bruṇniecības namā, un tur mēs sastapāmies ar generāli Sīmansonu, pulkvedi Kalniņu, pulkvedi Luteru, pulkvedi di Parke ${ }^{53}$ un kapt. Orbisonu. G̦enerālis 
Sīmansons sacīja, ka viṇi domā atbildēt vienkārši, ka nevēlas risināt nekādas lietas ar vīru, kuru ǵenerālis Judeņičs pasludinājis par nodevēju. Es ieteicu genenerālim Bērtam, ka atbildē, kurai būtu jābūt ìsai, propagandas nolūkos starp viņa paša karavīriem vajadzētu minēt Bermonta atsauksmi uz [it kā] uzvarošo akciju. Tomēr es saprotu, ka šī ziņojuma noslēgšanas brīdī (12. oktobra vakars) nekāda atbilde uz Bermonta aicinājumu nav nosūtîta. S. Dž. Talentss

Avots: National Archives (United Kingdom), Foreign Office, 371/3616/503-512.

\section{ATSAUCES UN SKAIDROJUMI}

${ }^{1}$ Par karadarbību un situāciju 1919. gada 8.-11. oktobrī sīkāk sk.: MĀRTIN̦š PENIķIS (virsred.). Latvijas atbrīvošanas kara vēsture. II daḷa. Rīga 1938, 64.-99. lpp.; ALEKSANDRS PLENSNERS. Vadība 1919. gada rudenī. In: Laiks, 19.08.1980., 4. lpp.; ĒRIKS JĒKABSONS. Latvijas armijas 1. Studentu bataljons Bermonta karaspēka uzbrukumā no 1919. gada 9. oktobra līdz novembra sākumam: kareivja Oskara Ozola liecība. In: Latvijas Kara muzeja gadagrāmata. XIV. Rīga 2013, 11.-30. lpp.

${ }^{2}$ Sīkāk sk.: ĒRIKS JĒKABSONS. Stāvoklis Latvijā pēc Cēsu kaujām: Sabiedroto misijas vadības un vācu pavēlniecības sarunas 1919. gada 19. jūlijā Vintapos pie Olaines stacijas. Situation in Latvia after Cēsis battles: talks between the leadership of Allies' missions and the German headquarters on 19 July 1919 in Vinatpi near Olaine railway station. In: Latvijas Arhīvi 2016, Nr. 3/4, 87.-106. lpp.; ËRIKS JĒKABSONS. Strazdumuižas pamiers 1919. gada 3. jūlijā un tā tiešās sekas: Lielbritānijas misijas vadītāja Stīvena Talentsa redzējums. Truce of Strazdumuiža in July 3, 1919 and its Direct Consequences: Perspective of Stephen Tallents, British Commissioner for the Baltic Provinces. In: Latvijas Universitātes Žurnāls. Vēsture 2017, Nr. 3, 171.-186. lpp.; ĒRIKS JĒKABSONS. Stāvoklis Rīgā 1919. gada augusta beigās un Pāvela Bermonta darbības konteksts: Lielbritānijas misijas vadītāja Stīvena Talentsa redzējums. Situation in Riga in the End of August 1919 and Context of Activities of Pavel Bermondt: View of the Head of British Mission. In: Latvijas Arhīvi 2018, Nr. 1/2, 95.-112. lpp.; ĒRIKS JĒKABSONS. Stāvoklis Latvijā 1919. gada jūlijā: Lielbritānijas pārstāvju viedoklis. Situation in Latvia in July, 1919: The perspective of British representatives. In: Latvijas Universitātes Žurnāls. Vēsture 2018, Nr. 5, 131.-144. lpp.; ĒRIKS JĒKABSONS. Cēsu kauju atskaņas Liepājā 1919. gada jūnija beigās: britu un amerikāṇu misiju dalībnieku liecības. Aftermath of Cēsis battles in Liepāja at the end of June 1919: British and American missions evidences. In: Latvijas Vēstures Institūta Žurnāls 2018, Nr. 3, 120.-142. lpp.

${ }^{3}$ National Archives (United Kingdom), Foreign Office, 371/3616/355.

${ }^{4}$ STEPHen TAllents. Man and Boy. London 1943, p. 366.

${ }^{5}$ Stīvens Džordžs Talentss (Stephen George Tallents, 1884-1958), Lielbritānijas valsts ierēdnis, kara laikā - virsnieks. No 1919. gada februāra - politiskās misijas vadītājs Baltijas valstīs.

${ }^{6}$ Ziṇojumu sākts rakstīt 9. oktobrī, bet tas noslēgts 12. oktobra vakarā. Bez komentāriem tas publicēts: Documents of British Foreign Policy 1919-1939. Ed. by E. L. Woodward and R. Butler. First Series. Vol. III. 1919. London 1949, pp. 147-152.

${ }^{7}$ Bentlijs (Bentley), Lielbritānijas armijas kapteinis, Politiskās misijas loceklis.

${ }^{8}$ Arturs Kopings (Arthur Copping, 1865-1941), britu žurnālists, publicists.

${ }^{9}$ Aleksis Krūms (1875-1943), Krievijas armijas štābkapteinis, Latvijas armijas kapteinis. 19. gadsimta 90. gados beidza komerckursus Anglijā, bija piederīgs anglikāņu ticībai. No 1919. gada jūlija bijis Armijas virspavēlnieka štāba rezervē, 14. oktobrī iecelts par sakaru virsnieku pie Sabiedroto misijas. 
${ }^{10}$ Runa ir par tikko saformētā 1. Studentu bataljona rotu, kas bija nosūtìta uz Pārdaugavu kā papildspēks.

${ }^{11}$ Ziṇojuma autors Bruṇniecības nama (tag. Saeimas ēkas) apzīmēšanai lieto tā vācisko nosaukumu Ritterhaus.

${ }^{12}$ Normens Djūhērsts (Norman Dewhurst, 1887 - pēc 1947), Lielbritānijas armijas kapteinis. Politiskās misijas loceklis, vadītāja vietnieks, vēlāk publicists.

${ }^{13}$ E. Hansens (Hansen), Lielbritānijas Politiskās misijas civilierēdnis.

${ }^{14}$ Berviks Kērtiss (Berwick Curtis, 1876-1965), Lielbritānijas Kara flotes kapteinis, vēlāk viceadmirālis. 1919. gadā karakuğa Abdiel komandieris.

15 Jards - garuma mērvienība, 0,91 metrs. Tātad runa ir apmēram par nepilniem 500 metriem.

${ }^{16}$ Kārlis Ulmanis (1877-1942), valstsvīrs. 1918.-1921. gadā Latvijas Pagaidu valdības Ministru prezidents.

${ }^{17}$ Vēlāk atmin̄ās S. Talentss minēto epizodi atceras nedaudz citādi, rakstot, ka K. Ulmanis, Z. Meierovics un citi ministri 9. oktobra vakarā automašīnā ieradušies Bruṇniecības namā, pazin̄ojuši, ka smagās militārās situācijas dēl spiesti pamest pilsētu, un pauduši prieku par S. Talentsa un A. Bērta apnememšanos palikt Rīgā, tādējādi mazinot ekscesu izcelšanās iespēju pēc Bermonta spēku ienākšanas. Šajā brīdī S. Talentss pasniedzis K. Ulmanim kasti ar portvīnu, lai "uzmundrinātu" viņu un ministru "nomākto garu" (dropping spirits). Sk.: TALLENTS, Man and Boy, p. 366. Jāatzīst, ka ticamāka ir ziņojumā minētā versija.

${ }^{18}$ Citēts no paziņojuma oriǵināla latviešu valodā.

${ }^{19}$ Kārlis Students (1885-1964), Krievijas armijas podporučiks, Latvijas armijas virsleitnants, no 1920. gada kapteinis, Ārlietu ministrijas ierēdnis. Pirms Pirmā pasaules kara dzīvojis Anglijā. No 1919. gada 3. jūnija dienējis 1. Atseviškās latviešu brigādes štābā, pēc tam Armijas virspavēlnieka štābā, kā angḷu valodas pratējs piekomandēts Lielbritānijas Politiskajai misijai.

${ }^{20}$ Atmin̄ās S. Talentss rakstīja par abu stāstīto kā sevis paša vakara pastaigas laikā redzēto, pieminot "bezgalīgu zemnieku vezumu rindas" un neaizsargāto tiltu. TALLENTS, Man and Boy, p. 367.

${ }^{21}$ Viljams Heistingss Ferovs (William Hastings Farrow, 1893-1946), Lielbritānijas armijas kapteinis, lidotājs. 1919. gadā neilgu laiku atradās dienestā Politiskajā misijā Rīgā.

${ }^{22}$ Čārlzs Elvings Eliss (1870-1942), ierēdnis, dzimis Rīgā. 1918. gadā vācu okupācijas laikā Rīgā internēts kā civilpersona. 1919.-1920. gadā Lielbritānijas Politiskās misijas civilierēdnis, vēlāk koktirgotājs Rīgā, kur miris.

${ }^{23}$ L. Kolass (L. Collas), Lielbritānijas Politiskas misijas civilierēdnis.

${ }^{24}$ Aleksandra bulvāris, vēlākais Brīivibas bulvāris.

${ }^{25}$ Alfrēds Bērts (Alfred Burt, 1875-1949), Lielbritānijas armijas generālmajors, 1919.-1920. gadā Sabiedroto militārās misijas vadītājs Latvijā un Lietuvā.

${ }^{26}$ Arčibalds Keizerlings (arī Keizerlings; Archibald von Keyserling, 1882-1951), Krievijas Kara flotes 2. ranga kapteinis, Latvijas armijas kapteinis, vēlāk admirālis. No 1919. gada augusta - Vācu zemessargu štāba vecākais adjutants, oktobrī - 1920. gada aprīlī - štāba nodalas priekšnieks.

${ }^{27}$ Harolds Aleksanders (Harold Alexander, 1891-1969), Lielbritānijas armijas pulkvežleitnants, vēlāk feldmaršals, aizsardzības ministrs. 1919. gada vasarā Politiskās misijas loceklis, 1919. gada augustā - 1920. gada februārī - Latvijas armijas Vācu zemessargu komandieris.

${ }^{28}$ A.D.C. - aide-de-camp (franču val.), adjutanta amata apzīmējums.

${ }^{29}$ Pāvels Bermonts-Avalovs (Pavel Bermondt-Avalov, 1877-1973), Krievijas armijas štābrotmistrs. 1919. gadā Rietumkrievijas armijas virspavēlnieks Latvijā un Lietuvā, pulkvedis, ǵenerālmajors.

${ }^{30}$ Eduards Kalniņš (1876-1964), Krievijas armijas pulkvedis, Latvijas armijas ǵenerālis. 1919. gada jūlijā - 15. oktobrī - Armijas virspavēlnieka štāba priekšnieka vietas izpildītājs.

${ }^{31}$ Vēlāk S. Talentss atcerējās, ka nakts Bruṇniecības namā pavadīta, guḷot savās gultās pilnā apgèèrbā un ar ieročiem pārliecībā, ka nakts gaitā pilsētā ienāks vācu karaspēks (no rīta bijis pārsteigums, ka tas nav noticis). TALLENTS, Man and Boy, p. 367. 
32 Zigfrīds Anna Meierovics (1887-1925), valstsvīrs. 1918.-1924. gadā Latvijas ārlietu ministrs.

${ }^{33}$ Dāvids Sīmansons (1859-1933), Krievijas armijas generālmajors, Latvijas armijas generālis. 1919. gada jūlijā - 16. oktobrī Latvijas armijas virspavēlnieks.

${ }^{34}$ Atmin̄ās S. Talentss piemin "padrūmas brokastis" (somewhat gloomy breakfast). TALLENTS, Man and Boy, p. 367.

${ }^{35}$ Nikolajs Judeṇičs (Nikolaj Yudenich, 1862-1933), Krievijas armijas infantērijas generālis, 1919.-1920. gadā Krievijas Ziemel̦rietumu armijas virspavēlnieks.

${ }^{36}$ Aleksejs Vandams (Aleksej Vandam, 1867-1933), Krievijas armijas generālmajors, publicists. 1919. gada jūlijā - 25. novembrī Krievijas Ziemel̦rietumu armijas štāba priekšnieks.

${ }^{37}$ Pjotrs Kondirevs-Kondzerovskis (Pjotr Kondirev-Kondzerovskij, 1869-1929), Krievijas armijas generālleitnants. No 1919. gada 2. oktobra Krievijas Ziemel̦rietumu valdības kara ministrs un armijas virspavēlnieka palīgs.

${ }^{38}$ Pavēles norakstā uzvārds kḷūdaini rakstīts kā Belmonts.

${ }^{39}$ Atminnās S. Talentss rakstīja, ka šĩs tikšanās laikā K. Ulmanis un pārējie joprojām bijuši pārliecināti par gaidāmo pilsētas krišanu. Sk.: TALLENTS, Man and Boy, p. 367.

40 Tomass Džeimss Orbisons (Thomas James Orbison, 1866-1938), ASV ārsts, virsnieks. 1919.-1920. gadā bija Amerikas Palīdzības administrācijas pārstāvis Latvijā, no 1919. gada augusta vadīja Bērnu ēdināšanas programmas realizāciju.

${ }^{41}$ Amerikas palīdzības administrācija (American Relief Administration), ASV palīdzības organizācija, kas 1919.-1922. gadā darbojās Latvijā, sniedzot valstij, pašvaldībām un iedzīvotājiem palīdzību, piegādājot pārtiku, apǵērbu u. c.

${ }^{42}$ Bēržess (Burges), Lielbritānijas kara flotes virsnieks, precīzākas ziṇas nav izdevies noskaidrot.

${ }^{43}$ Viktors Varenders (Victor Warrender, 1899-1993), Lielbritānijas armijas leitnants, vēlāk politisks darbinieks. 1919. gadā Lielbritānijas Politiskās misijas loceklis Baltijas valstīs.

${ }^{44}$ Vilhelms fon Firkss (Wilhelm von Fircks, 1870-1933), inženieris, politiḳis. 1919. gadā bija Vācbaltiešu nacionālās komitejas priekšsēdētājs.

45 Jānis Luters (1882-1942), Krievijas armijas štābkapteinis, Latvijas armijas pulkvedis-leitnants. 1919. gada jūlijā-oktobrī Armijas virspavēlnieka štāba Inspekcijas dal̦as priekšnieks.

${ }^{46}$ Runa par Latvijas armijas virspavēlnieka štābu.

${ }^{47}$ Aplūkojamā laikā valdība bija nosūtījusi delegācijas uz Igauniju un Poliju palīdzības meklējumos.

${ }^{48}$ Runa ir par Iekšlietu ministrijas toreizējo ēku Aleksandra (tag. Brīvības) ielā 37, tā atradās Stabu ielas stūrī, kur 1919. gadā bija arī vairākas citas valsts un armijas iestādes.

${ }^{49}$ Lielbritānijas Kara flotes dienesta pakāpe.

${ }^{50}$ Henrijs N. Stodarts (Henry N. Stoddart), Lielbritānijas kara flotes virsnieks, Politiskās misijas loceklis, kasieris.

${ }^{51}$ Atmin̄ās S. Talentss atzīmēja, ka izdevis stingru aizliegumu misijas locekḷiem atstāt Bruṇniecības namu bez vina aţ̦aujas. Sk.: TALLENTS, Man and Boy, p. 367.

${ }^{52}$ Ostins (arī Ougustins; Augustine) Henrijs Kīnens (Henry Keenan), Lielbritānijas armijas izlūkdienesta majors, 1919. gada pavasarī - Militārās misijas vadītājs Liepājā un Rīgā, pēc tam tās vadītāja vietnieks. 10. oktobrī no rīta Militārās misijas vadītājs A. Bērts bija nosūtījis O. Kīnenu noskaidrot Daugavā stāvošo divu britu karakug̣u stāvokli, bet, viṇam atrodoties uz klāja, tika pieņemts lēmums piestātni atstāt un aizbraukt Daugavas grīvas virzienā, lai izvairītos no varbūtējas apšaudes. Tādā veidā viņš nonāca Jaunmīlgrāvī un pēc tam aizveda uz Vecrīgu arī abām britu misijām adresētos pasta sūtījumus. Sk.: TALLENTS, Man and Boy, p. 367.

${ }^{53}$ Emanuels di Parkē (Emmanuel du Parquet, 1869-1933), Francijas armijas pulkvežleitnants. 1919.-1920. gadā Militārās misijas vadītājs Baltijas valstīs. 